\title{
School climate in peer bullying: observers' and active participants' perceptions
}

\author{
Sonja Pečjak* and Tina Pirc \\ Department of Psychology, Faculty of Arts, University of Ljubljana, Slovenia
}

\begin{abstract}
Peer bullying is a phenomenon present in all schools. The school as an institution has a major role in limiting peer bullying. The primary goal of the study was to determine how different groups of students perceived school climate in relation to peer bullying regarding their role in peer bullying (active participants: bullies, victims, bully-victims and non-active participants: observers). 414 students (from 18 primary and secondary schools) responded to The School Climate Bullying Survey (SCBS; Cornell, 2012), which measures the incidence of various forms of peer bullying and three dimensions of school climate (prevalence of teasing and bullying, aggressive attitudes, and willingness to seek help). The results showed that the active participants in peer bullying report a frequent presence of verbal and social bullying (54\% and $40 \%$, respectively) and a significantly lower frequency of physical and cyber bullying (14\%). The largest differences between the groups of students were found in their perceptions of the prevalence of aggressive attitudes and willingness to seek help in a school context. In the perceptions of both of these dimensions we found a high degree of similarity between the groups of bullies and victim-bullies, and between the groups of victims and observers. The first two groups, when compared to the victims and observers, perceived to a greater extent that school allows aggression as a way of affirmation among peers and in school in general, and that neither teachers nor peers do not stop the bullying, which discourages the victims from seeking help from them. The results confirmed the existence of the association between students' perceived school climate by bullying and their behavior (roles) in peer bullying.
\end{abstract}

Keywords: peer bullying, perceived school climate, bullies, victims, observers

\section{Šolska klima pri medvrstniškem nasilju: zaznave opazovalcev in aktivnih udeležencev}

\author{
Sonja Pečjak* in Tina Pirc \\ Oddelek za psihologijo, Filozofska fakulteta, Univerza v Ljubljani
}

Povzetek: Medvrstniško nasilje (MVN) je pojav, prisoten v vseh šolah. Pri omejevanju MVN ima šola kot institucija pomembno vlogo. Glavni cilj naše študije je bil ugotoviti, kako posamezne skupine učencev glede na vlogo v MVN (aktivni udeleženci: nasilneži, žrtve, žrtve-nasilneži in neaktivni udeleženci: opazovalci) zaznavajo šolsko klimo v povezavi z medvrstniškim nasiljem. V raziskavi je sodelovalo 414 učencev iz 18 osnovnih in srednjih šol. Uporabili smo Vprašalnik šolske klime pri medvstniškem nasilju (SCBS, Cornell, 2012), ki meri pojavnost različnih oblik MVN ter tri dimenzije šolske klime (dopuščanje nasilja, dopuščanje agresivnih stališč in spodbujanje iskanja pomoči). Rezultati so pokazali, da aktivni udeleženci MVN poročajo o pogostejši prisotnosti verbalnega in odnosnega nasilja (v 54 in 40 \%) ter o pomembno manjši pogostosti pojavljanja fizičnega in spletnega nasilja (14 \%). V zaznavah dimenzij šolske klime smo med skupinami učencev našli največje razlike pri dopuščanju agresivnih stališč učencev in iskanju pomoči. Ugotovili smo, da v zaznavah obeh dimenzij obstaja precejšnja podobnost med skupinama nasilnežev in nasilneževžrtev ter med skupinama žrtev in opazovalcev. Prvi dve skupini v pomembno večji meri zaznavata, da šolsko okolje dopušča agresivnost kot način afirmacije med vrstniki in v šoli nasploh ter da niti učitelji niti vrstniki ne zaustavljajo nasilja in da zato pri njih ni smiselno iskati pomoči. Rezultati potrjujejo obstoj povezanosti učenčevih zaznav šolske klime pri MVN in njihovega vedenja (vlog) pri tem nasilju.

Ključne besede: medvrstniško nasilje, zaznana šolska klima, nasilneži, žrtve, opazovalci

\footnotetext{
*Naslov/Address: red. prof. dr. Sonja Pečjak, Oddelek za psihologijo, Filozofska fakulteta, Univerza v Ljubljani, Aškerčeva 2 , 1000 Ljubljana, e-mail: sonja.pecjak@ff.uni-lj.si
}

Članek je licenciran pod pogoji Creative Commons Attribution 4.0 International licence. (CC-BY licenca). The article is licensed under a Creative Commons Attribution 4.0 International License (CC-BY license). 


\section{Peer bullying}

Peer bullying is a phenomenon prevalent in schools all around the world, irrespective of national, cultural, and political characteristics of the country. Some schools are dealing with this problem openly (Sullivan, 2011), while others conceal the bullying or even deny it. When can we talk about peer bullying? Whenever a student is repeatedly exposed to aggressive behavior by a peer or a peer group over a longer period of time (Olweus, 1993) or when there is a conscious, deliberate, and repeated aggressive behavior and manipulative and/or exclusionary behavior of one or more persons against one or more (of other) people who are physically, mentally, or socially disadvantaged compared to the bully (Smith, Ananiadou, \& Cowie, 2003; Sullivan, 2011). In school, the following types of bullying take place (Berger, 2007): physical bullying (e.g., pushing, kicking, damage to the property of another), social bullying (e.g., exclusion or social isolation), verbal bullying (e.g., making quips), and cyberbullying (e.g., spreading rumors via the internet or sending insulting telephone messages). Students appear in the roles of active participants: bullies (perpetrators of an aggressive act to other peers), victims (targets of bullies) and victim-bullies at the same time. In the fourth group, there are observers of peer bullying (students who are present as witnesses to what is going on). The criterion for grouping students into individual roles is the frequency of occurrence of aggressive behavior by students towards their peers in a certain period. The experts' guidelines are one to two occurrences of a particular type of bullying in the past month (Cornell, 2012; Olweus, 1993), which we also took into account in our study.

Previous studies, which included students from the same age group as ours (12 to 18 years), have reported different frequencies of peer bullying in various countries. The percentage of bullying ranges from 12 to $42 \%$ (Benitez \& Justicia, 2006; Bradshaw, Sawyer, \& O’Brennan, 2007; U.S. Department of Education, 2015; World Health Organization, 2004; Wong, Lok, Wing Lo, \& Ma, 2008). A common finding of studies from different countries is that among students verbal bullying is the most common, social bullying is somewhat less frequent, and physical bullying the least usual (Marsh et al., 2011; Polak, Smrtnik Vitulić, \& Vošnjak, 2011; Wang, Iannotti, \& Nansel, 2009). However, the share of cyberbullying is increasing (Kowalski, Giumetti, Schroeder, \& Reese, 2012; Smith et al., 2008; Wang et al., 2009), although it is still behind traditional bullying (U.S. Department of Education, 2015). It is important to point out that it is difficult to compare data from different studies because researchers use different criteria to identify the role of the victim and the bully and to explore the presence of bullying in different age groups of students and different schools/countries. It is particularly hard to assess the proportion of victims and bullies in cyberbullying since the development of information communication technology continually provides new forms of such bullying.

In our study, we were interested in the proportions of individual roles of students (victims, bullies, victim-bullies, and observers) in all four forms of peer bullying (physical, verbal, social, and cyber). In spite of certain common characteristics of peer bullying, it is reasonable to distinguish between individual forms of peer bullying, because, as the researchers point out (Marsh et al., 2011; Wang et al., 2009), each one has some distinctive features. For example, although physical bullying appears the least frequently, teachers and students perceive it as the most serious and consequently stop it earlier compared to the other forms of bullying (Posnic \& Košir, 2016; Pečjak \& Pirc, 2015). Because student observers are a large group, which is capable of stopping bullying in a classroom, it is important how sensitive they are to different forms of bullying. If they find verbal bullying to be acceptable, then their readiness to stop the bully and support the victim decreases.

\section{Theoretical background for understanding peer bullying in school context}

In order to understand the fact that peer bullying in schools is a phenomenon that is difficult to eradicate, it has to be taken into account that peer bullying is not just about the relationship between two students - the bully and the victim. It is placed in a broader social context of a school/classroom. Therefore, our understanding of this phenomenon is derived from socio-ecological theories (i.e., Bronfenbrenner's theory, 2004) and social theories, e.g., model of planned behavior (Ajzen \& Madden, 1986). These theories explain how an individual perceives social incidents, including peer bullying which affects his/her behavior, and how these perceptions affect his/her behavior.

Bronfenbrenner's ecological systems theory (2004) explains that any conduct by an individual in a given social system affects other individuals in the system and that they have a reverse effect (back) to the individual. From this theory, Sullivan (2011) formed a model of "ripple effect", which explains the dynamics of the process of peer bullying more precisely. The author compares bullying with a stone that is thrown into the water, and around which waves are then spreading in concentric circles. In the case of peer bullying, the primary victim of bullying is an individual student, and at the secondary level the victims of this violence are parents and student-victims' families; but it also affects those who witness such violence - their peers in the classroom or other students at the school who hear about bullying. It can cause anxiety and feelings of unsafety or it may raise feelings of shame due to their lack of trying to stop the bullying. Therefore, the teacher's/school's reaction to peer bullying is very important because it represents symbolic information for all the students in the classroom/school. If they see that the teacher/school is trying to stop all instances of bullying, then it is more likely that they will not approve of it or that they will tell adults (teachers or parents) about it. However, if the school's response to peer bullying is weak, this sends a message to the bullies that they may continue with bullying without being punished. This study is the first exploratory study in Slovenia to examine the way students perceive the messages of peer bullying conveyed by the school/teachers.

The model of planned behavior (Ajzen \& Madden, 1986) also explains the phenomenon of peer bullying 
among students in the classroom. Behavioral intentions and behavior of students are affected by i) the student's personal beliefs about peer bullying (positive or negative attitudes towards bullying), ii) their subjective norms as generally accepted standards of behavior and feelings (whether they feel bullying is acceptable or unacceptable, which is under the influence of the reference group to which they belong), and iii) their perceived behavioral control (student's belief about his/her competence for performing the bullying and beliefs about how external factors affect this behavior). If a student has positive attitudes towards peer bullying, if they believe bullying is acceptable (which is under the influence of their peers' perceptions of it), and if the student estimates that external factors (the school, teachers) will not stop this bullying, then the student more quickly becomes a bully in relationships with his or her peers.

As it is apparent from both presented theories (the ecological theory and the model of planned behavior), peer bullying in a student's behavior is the result of student's individual characteristics and the influence of the social environment (norms, rules and values) on the student. All these social environment factors form the construct of school climate. Therefore, in our study, we considered how students perceive school climate regarding peer bullying. We had in mind that schools/teachers, with their reactions to bullying, send students clear messages about what is and what is not acceptable in (their) school. This enables them to contribute to the shaping of students' personal beliefs and their subjective norms about the acceptability of different forms of behavior, which affect their behavior and continue to influence the shaping of the school climate.

\section{School climate and peer bullying}

School climate is a multidimensional construct and refers to the quality and character of social interactions at school. It is defined by the norms, values, rules, organizational structures, and relationship patterns unique to each school (Cohen, McCabe, Michelli, \& Pickeral, 2009). Positive school climate may be a protective factor for the school adjustment of students in general, for their academic adjustment (Lacey \& Cornell, 2011), and for different risk behaviors, as well as for the students' aggression towards their peers (Cook, Williams, Guerra, Kim, \& Sadek, 2010; Hong \& Espelage, 2012).

Researchers point out that there is a reciprocal relationship between peer bullying and school climate (Brandyopathyay, Cornell, \& Konold, 2009; Golstein, Young, \& Bold, 2008). Violent behavior among peers affects school/classroom climate, e.g., the relations and the atmosphere among students. Namely, students avoid interactions with the bullies, they feel fear, and their feelings of safety are low in general. Waasdorp, Pas, O'Brennan, and Bradshaw (2011) reported that each time peer violence increases by $1 \%$, the likelihood that students feel safe at school is reduced by $3 \%$. Therefore, witnessing peer bullying on frequent occasions causes a lower sense of safety in all students, both in the victims and the observers, and indirectly impairs school climate (Golstein et al., 2008). The school staff (particularly teachers) can do the most in stopping the bullying, but it does need to be pointed out that a meta-analysis by Denny et al. (2015) showed that the peers' and not the teachers' intervention had a greater impact on reducing the bullying. However, there is evidence that school climate has a reverse effect on student behavior; if students know that certain rules of interpersonal behavior have to be respected and that they will have to take responsibility for bullying, many classroom bullies will cease this behavior (Salmivalli \& Voeten, 2004).

\section{Research problem}

The first aim of our study was to investigate the frequency of various forms of bullying (physical, verbal, social, and cyber) in relation to the role of students in peer bullying.

Sullivan (2011) compares peer bullying in schools with an iceberg, where only a small part of peer bullying is identified and dealt with. One of the reasons behind this is that students report bullying only on rare occasions. Adair, Dixon, Moore, and Sutherland (2000) revealed that students report peer bullying to teachers and/or other adults in only $21 \%$ of the cases. Therefore, in our study, we were interested in how often our students report bullying from their peers in general and how often they report what happened to them to teachers. We assumed that students would rarely report being bullied to the teachers and that they would inform their parents or peers about it more frequently; this assumption was based on the results of studies in other countries (Ttofi \& Farrington, 2011). As a reason for this fact, researchers state that students most often do not report peer bullying to teachers due to their belief that they are not successful in preventing or stopping it.

Rigby and Bagshaw (2003) stated that approximately $40 \%$ of Australian 14-year-olds believe that their teachers do not do enough to stop the bullying. Fekkes, Pijpers, and VerlooveVanhorick (2005) reported similar results for Dutch students between 9 and 11 years of age. Only slightly over half of the students $(53 \%)$ inform the teachers about bullying, but onethird of them believe that after the disclosure the situation does not improve, while another third feels it becomes even worse. Such conditions in the classroom have hidden effects on the victims, such as feeling frightened, being under constant pressure, and the resulting fear of attending school. Therefore, the main goal of our study was to explore how students in different roles in peer bullying perceive school climate regarding peer bullying and to find out if there are any significant differences between them considering these roles. We were interested in finding out in what way student-victims, bullies, victim-bullies, and observers perceive "messages" about acceptability or unacceptability of bullying behavior coming from their school or teachers. In line with socio-ecological theory (Bronfenbrenner, 2004) and the theory of planned behavior (Ajzen \& Madden, 1986), these perceptions of the environment substantially affect the shaping of students' norms in perceived behavior control and the student's behavior. According to these theories, we assumed that bullies and victim-bullies would perceive school climate in peer bullying significantly differently from the victims and observers, which would consequently have an impact on their behavior. 


\section{Method}

\section{Participants}

In total, 414 students from 18 Slovenian schools participated in the study, 113 of which were primary $(27.3 \%)$ and 301 secondary school students $(72.7 \%)$. The sample was a convenient one. Students from the 7 th to 9 th grades were included in the primary school sample $(20.4 \%$ from the 7 th grade, $46.0 \%$ from the 8 th grade, and $33.6 \%$ from the 9 th grade); in the secondary school sample, there were students from the $3 \mathrm{rd}(42.9 \%)$ and 4 th year $(57.1 \%)$. There were more girls than boys in primary and secondary samples $(53.1 \%$ in primary school sample and $58.1 \%$ in secondary school sample). However, no significant differences were found regarding gender representation, $\chi^{2}(1)=.85, p=.21$.

The average age of the participants was 13.31 years $(S D$ $=1.09)$ and 17.85 years $(S D=1.00)$ for primary school and secondary school students, respectively.

\section{Instruments}

The School Climate Bullying Survey - SCBS. SCBS (Cornell \& Sheras, 2003; Cornell, 2012) has four parts: the first part assesses the frequency of bullying or being bullied by others (physical, verbal, social, and cyber bullying); the second part asks students about whom they tell about being bullied, the third part is about the locations where bullying occurs, and the fourth part comprises of school climate scales. We translated three parts of the survey for the purposes of our study: the first, the second and the fourth. We used the standard procedure of translation; two independent experts translated the survey into Slovenian, and two independent English language experts translated it back to English, which was followed by coordinating both translations and forming the final version of the questionnaire. Students were asked to read the items which pertained to their behavior in school and to respond to them most honestly. In the beginning, they read a general definition of bullying: »Bullying is defined as the use of one's strength or popularity to injure, threaten, or embarrass another person on purpose. Bullying can be physical, verbal, social, or cyber. It is not bullying when two students who are comparable in strength or power have a fight or argument.«

Next, they assessed their behavior in general, i.e., they responded to two items about performing bullying or being the victim of bullying in the past month ( 2 items).

In the final section of the first part of the survey the students were given descriptions of physical, verbal, social, and cyber bullying ( 2 items for each type of bullying) in the past month. E.g., »Social bullying involves getting others repeatedly to ignore or leave someone out on purpose. During the past month (30 days) at school: a) I have been socially bullied. b) I have socially bullied another student." To each statement the students responded on a 4-point scale indicating the frequency of performing bullying behaviors or being bullied by others $(1-$ never, $2-1-2$ times a month, 3 - once a week, 4 - several times a week).
The second part of SCBS asks if the student has told someone that they were bullied in the past month (Yes/No) and to whom did they tell (a friend, teacher/another adult at school, parent).

The fourth part of SCBS determines three factors of school climate regarding bullying (Cornell \& Sheras, 2003; Cornell, 2012): prevalence of teasing and bullying (4 items, e.g., Students here often get teased about their clothing or physical appearance.; Cronbach $\alpha$ in our sample was .75), aggressive attitudes (7 items, e.g., If you fight a lot, everyone will look up to you.; $\alpha=.80$ ), and willingness to seek help (9 items, e.g., Students here try to stop bullying when they see it happening.; $\alpha=.79$ ). Students responded on a 4 -point scale ( 1 - strongly disagree, 4 - strongly agree), with higher results indicating that the measured characteristic was more expressed.

To test the construct validity of the SCBS on the Slovenian sample, we carried out a confirmatory factor analysis in Mplus 7 (Muthén in Muthén, 1998-2010). We used the WLSMV estimator, which is the default estimator for ordered categorical variables. When evaluating the model fit, we used the following cut-off values of fit indices: RMSEA $<.08$, CFI/TLI $>$ (or close to) .90. The fit of the 3-factor model was satisfactory, $\chi^{2}(167)=581.7, p<.01 ; \mathrm{RMSEA}=.078 ; \mathrm{CFI}=.89$; $\mathrm{TLI}=.87$. The standardized factor loadings were adequately high: prevalence of teasing and bullying (factor 1$), M(\lambda)=$ .54 ; aggressive attitudes (factor 2$), M(\lambda)=.69$; willingness to seek help (factor 3 ), $M(\lambda)=.60$. The correlation between factors 1 and 2 was $.49,-.14$ between factors 1 and 3 , and - .55 between factor 2 and 3 .

\section{Procedure and data analysis}

Data were collected with The School Climate Bullying Survey in primary and secondary schools in May 2015. Students were divided into groups of bullies, victims, and victim-bullies if bullying behavior was present 1-2 times per month or more often, which is recommended by Cornell (2012) and Olweus (1993) as a standard for determining individual roles of students in peer bullying. This was done based on their responses regarding all four forms of peer bullying (physical, verbal, social, and cyber). Students who did not report bullying behavior were considered to be in the group of observers. $\chi^{2}$ and ANOVA were used to determine the differences between different groups of students by individual forms of peer bullying. Eta-squared $\left(\eta^{2}\right)$ and Cohen's $d$ were used as measures of effect sizes.

\section{Results and discussion}

\section{The forms of peer bullying from the perspective of students in different peer bullying roles and reporting about bullying}

We were interested in the distribution of different roles of students (victims, bullies, victim-bullies, and observers) by individual forms of peer bullying and possible differences between students regarding different forms of peer bullying (Table 1). 
It is apparent from Table 1 that verbal bullying is most frequent among students. Namely, more than a half (53.7\%) of all students actively participate as victims, bullies, or in both roles in this type of peer bullying. This is followed by $40 \%$ of students who are active participants in social bullying. Compared to these two groups, there are fewer students who actively engage in physical and cyber bullying (14\%). In comparison to a similar study by Wang et al. (2009) in American adolescents, our results show that verbal and cyber bullying is present in the group of Slovenian adolescents in approximately the same proportion as is in the American adolescents (in the USA: verbal bullying in 53.6\% and cyberbullying in $13.6 \%$ ), but there is substantially more physical (20.8\%) and social bullying (51.4\%) in American adolescents.

Similar shares of verbal and social bullying were also found in other studies (Marsh et al., 2011; Olweus, 1995; Polak et al., 2011; Skumavc, 2016). The established distribution probably reflects a broader social attitude towards verbal and social bullying as more acceptable forms of bullying, which is also apparent in a school context. Or, as can be drawn from the model of planned behavior (Ajzen \& Madden, 1986), verbal and social bullying is becoming a subjective norm in students as well as in teachers. Studies show that teachers and students recognize these types of bullying as less serious and threatening and that teachers tolerate them more and respond to them later or not at all (Bauman \& Del Rio, 2006; Craig, Bell, \& Leschied, 2011; Pečjak \& Pirc, 2015). By allowing verbal and social bullying at school, this kind of behavior becomes more and more acceptable and normative. Group norms about the admissibility of peer bullying are formed, and they affect individual's subjective norms (Ajzen \& Madden, 1986).

Accordingly, we found significantly more verbal and social bullies than physical and cyber bullies. Most frequently the same students become victims as well as bullies in verbal bullying, which shows that in verbal bullying almost a quarter of students react aggressively - they answer disrespectfully and use insulting expressions and/or offending words. This is probably related to group norms becoming more and more tolerant of this form of bullying. A smaller proportion of students taking both roles (victims and bullies) was found in social bullying and an even smaller one in cyber and physical bullying. Yet, comparative analyses of studies on cyberbullying before the year 2000 and after the year 2010 indicate that the share of cyberbullying is increasing in line with new technology development not only in primary, but also in secondary school students (Kessel Schneider,
O’Donnell, Sueve, \& Coulter, 2012; Kowalski et al., 2012).

Further, we were able to discover some patterns indicating specific characteristics of individual forms of bullying from Table 1 . There are fewer bullies in verbal, social, and cyber bullying than victims, suggesting that bullies in these types of bullying choose more than one victim. This was already noticed by other authors (Olweus, 1995; Pečjak, 2015). The reverse holds true for physical bullying, where there is a higher proportion of bullies than victims. This implies that an individual student is probably exposed to physical bullying behavior from several peers because the student victims' response to bullying is passive and weak. In most cases, they ignore the bullies and leave the situation, which usually does not stop the aggressors. They rarely use more active strategies for confronting the bully, which are more effective (Hunter \& Boyle, 2004; Waasdorp \& Bradshaw, 2011).

Next, we were interested in whether students report the bullying that takes place in their school and whether they inform teachers about it. We found that more than a half of the students were not victims of any type of bullying (56.5\%) in the previous month. However, among 179 students who were victims of peer bullying, as much as 141 (79\%) of them did not share their experience with anyone and only 38 students $(21 \%)$ told about it to someone else. In $58 \%$ of these cases, the students confided to their friends, the next in line were parents $(24 \%)$, and the last were teachers to whom only $18 \%$ of the students told about being bullied. Our result is in accordance with the studies performed in the USA and Australia, where researchers report that only between 20 and $30 \%$ of students report about being bullied (Adair et al., 2000; Ttofi \& Farrington, 2011).

Based on these results, an assumption could be made that students in general rarely report bullying, and most of the victims probably try to face the situation alone. It is important to note, however, that research results indicate that seeking help from adults and peers works better than trying to handle the situation alone (Davis \& Nixon, 2011). Moreover, from the results of our study, it was also apparent that the percentage of students who do tell the teachers about bullying is smaller than in some other countries (Rigby, 2016). This leads us to the assumption that students in Slovenia do not trust teachers enough and do not perceive them as competent for dealing with peer bullying effectively. It is also possible that they perceive school climate regarding peer bullying in such a way that they consider reporting bullying to teachers as pointless, where such an action does not change anything, or the situation gets even worse after the intervention is made by the teachers.

Table 1. The frequency of roles in peer bullying $(P B)$ stratified by the form of bullying

\begin{tabular}{lrrrrrrrrr}
\hline & \multicolumn{2}{c}{ Victims (V) } & \multicolumn{2}{c}{ Bullies (B) } & \multicolumn{2}{c}{ Victim-bullies (V-B) } & \multicolumn{2}{c}{ Observers } & $\begin{array}{c}\text { Active participants } \\
\text { in PB (V, B, V-B) }\end{array}$ \\
\hline & $f$ & $\%$ & $f$ & $\%$ & $f$ & $\%$ & $f$ & $\%$ & $\%$ \\
\hline Physical & 10 & 2.4 & 31 & 7.7 & 16 & 3.9 & 355 & 86.0 & 14.0 \\
Verbal & 74 & 17.7 & 51 & 12.2 & 95 & 22.8 & 193 & 46.3 & 53.7 \\
Social & 58 & 14.0 & 53 & 12.8 & 54 & 13.2 & 248 & 60.0 & 40.0 \\
Cyber & 25 & 6.1 & 16 & 3.9 & 17 & 4.1 & 354 & 85.9 & 14.1 \\
\hline
\end{tabular}

Note: $N_{\text {physical }}=413 ; N_{\text {verbal }}=413 ; N_{\text {social }}=413 ; N_{\text {cyber }}=412$; active participants: V - victims, B - bullies, V-B - victim-bullies. 


\section{Perceived school climate regarding peer bullying in relation to student roles in peer bullying}

We were interested in how different groups of students (victims, bullies, victim-bullies, and observers) perceive school climate regarding peer bullying. Students were assigned to different roles on the basis of their responses to the question about their role in bullying in general without considering individual forms of peer bullying. In the school climate dimensions, we present the perceptions of individual groups of students with regard to the prevalence of teasing and bullying, aggressive attitudes, and willingness to seek help.

We used one-way ANOVA for independent samples to determine whether there were any significant differences in the perceptions of school climate dimensions regarding peer bullying between these groups of students. First, we performed Levene's test for testing the equality of variances, which showed no significant differences between the variances of individual groups of students for any of the dimensions (for prevalence of teasing and bullying $F(3,407)=.98 ; p=$ .40 ; for aggressive attitudes $F(3,404)=.86 ; p=.46$ and for willingness to seek help $F(3,403)=.477 ; p=.70)$.

Our data revealed the existence of significant differences in perceptions of all three dimensions of school climate regarding peer bullying, which is consistent with the findings of other studies (Bandyopadhyay et al., 2009; Elliot, Cornell, Gregory, \& Fan, 2010). There were highly significant differences in dimensions of aggressive attitudes and willingness to seek help and in the prevalence of teasing and bullying between victims, bullies, victim-bullies, and observers (Table 2).

Post-hoc tests with Bonferroni correction for pairwise comparisons of group means showed no significant differences between active participants in peer bullying (victims, bullies, and victim-bullies) and the observers in their perceptions of teasing and bullying (the mean difference between victims and observers was $.99 ; p=.40$; the mean difference between bullies and observers was .67; $p=0.52$; the mean difference between victim-bullies and observers was $1.00 ; p$
$=.51)$. However, active participants, in general, agreed more strongly that students got teased about their clothing, physical appearance, and ethnicity than the observers did, but the effect size of these differences was small $\left(\eta^{2}=.02\right)$.

Larger differences between individual groups of students were found in their perceptions of how many aggressive attitudes their school allowed for and whether these attitudes were reflected in the behavior of students. Here the differences between groups of students were highly significant with a large effect size $\left(\eta^{2}=0.14\right)$.

There were no significant differences between student victims and observers in their perceptions that school allowed for aggressive attitudes (the mean difference was .48; $p=1.00$ ). The groups of bullies and victim-bullies, however, agreed that school allowed for aggressive attitudes significantly more strongly than victims and observers (the mean difference between bullies and observers was $3.13 ; p<.01$; the mean difference between bullies and victims was 3.61; $p<.01$; the mean difference between victim-bullies and observers was $4.68 ; p<.01$; the mean difference between victim-bullies and victims was $5.16 ; p<.01)$.

We can conclude that bullies and victim-bullies agreed more strongly that their school environment allowed for aggressiveness as a way of affirmation among peers and at school, in general, more than victims and observers did. Compared to victims and observers, they also agreed more strongly that some students deserved to be victims and that aggressiveness is acceptable in some situations (e.g., if someone is teasing you or trying to hit you). The perception of these attitudes is called perceived behavioral control by Ajzen and Madden (1986) and can encourage bullies and victim-bullies to behave aggressively.

Although the perception of aggressive attitudes, which are accepted in certain schools, do not necessarily reflect students' behavior, allowing for them had the most predictive power in explaining the position of a bully (Pečjak \& Pirc, 2017). At the same time, these perceived »school attitudes" indicate group norms, which take place in a classroom/school regarding aggressiveness (Salmivalli \& Voeten, 2004) and represent one of the elements of the model of planned behavior (Ajzen \& Madden, 1986). Namely, if students perceive that school allows aggressive behavior as an acceptable form

Table 2. One-way ANOVAs for differences in perceptions of school climate by peer bullying between individual groups of students

\begin{tabular}{|c|c|c|c|c|c|c|c|c|}
\hline & & $N$ & $M$ & $S D$ & $F$ & $d f$ & $p$ & $\eta^{2}$ \\
\hline \multirow{4}{*}{$\begin{array}{l}\text { Prevalence of teasing and } \\
\text { bullying }\end{array}$} & Victim & 28 & 11.79 & 2.77 & 2.96 & 3,397 & .032 & .022 \\
\hline & Bully & 56 & 11.50 & 2.50 & & & & \\
\hline & Victim-bully & 23 & 11.73 & 2.43 & & & & \\
\hline & Observer & 294 & 10.73 & 2.79 & & & & \\
\hline \multirow{4}{*}{ Aggressive attitudes } & Victim & 28 & 11.14 & 3.22 & 21.38 & 3,397 & $<.001$ & .139 \\
\hline & Bully & 56 & 14.80 & 3.85 & & & & \\
\hline & Victim-bully & 23 & 16.30 & 3.52 & & & & \\
\hline & Observer & 294 & 11.65 & 3.73 & & & & \\
\hline \multirow{4}{*}{ Willingness to seek help } & Victim & 28 & 25.75 & 5.45 & 7.84 & 3,397 & $<.001$ & .056 \\
\hline & Bully & 56 & 22.61 & 4.64 & & & & \\
\hline & Victim-bully & 23 & 21.65 & 3.64 & & & & \\
\hline & Observer & 294 & 25.12 & 4.81 & & & & \\
\hline
\end{tabular}


of affirmation in a classroom, then such a norm affects individual students through the process of peer group pressure or conformity. For example, even if a student thinks that bullying is wrong, the classroom influences may encourage him to join in the bullying or at least not to show sympathy for the victim. Therefore, these kinds of perceived beliefs in students have to be addressed by all school staff and reduced through constant communication in the classroom community (Gottfredson, Gottfredson, Payne, \& Gottfredson, 2005).

The same bipolar division of the students into two broad categories can be found in their perceptions of classroom climate regarding willingness to seek help. Post hoc tests revealed significant differences between victims and bullies (the mean difference was $3.13 ; p=0.02$ ) and between victims and victim-bullies (the mean difference was $4.29 ; p=0.01$ ). There were also significant differences between bullies and victim-bullies compared to the observers (the mean difference between bullies and observers was $-2.51 ; p<.01$; the mean difference between victim-bullies and observers was -3.67 ; $p<.01)$.

Between the first group (bullies and victim-bullies) and the second one (victims and observers), there was a highly significant difference with medium effect size $(d=.67)$. Compared to the second group, the first group of students perceived school climate as an environment with significantly less encouragement of students to seek help when bullied. The first group agreed less that at school both teachers and peers stop the bullying if they witness it and that the school has clear rules on the consequences of bullying. This group also agreed less that teachers as individuals care for the students than the other group did.

They also agreed less that they would seek help from them if they witnessed the bullying or became victims themselves. If bullies and victim-bullies perceive school environment as unsupportive to the victims, this sends a message to them that the path for performing peer bullying is free. In contrast, the second group - victims and observers - perceived school climate as significantly more supportive, and they also perceived the teachers and peers as individuals' to whom they would more probably turn to in case of being bullied. Such perceptions of victims and observers are particularly important, because as shown by previous studies (Craig, Pepler, Connolly, \& Henderson, 2001, Elliot et al., 2008), a lack of confidence in the teachers' ability to intervene is one of the key reasons why students often do not seek help from them.

On the other hand, some authors report (Hunter \& Boyle, 2004) that willingness to seek help from teachers and peers is an effective strategy, which helps the victims of peer bullying to resolve their role in less than two years (Smith, Talamelli, Cowie, Naylor, \& Chauhan, 2004).

Finally, some of the limitations of the results of our study should be mentioned. First, the results were gathered with a self-report technique, which is a less precise measure for identifying the roles of bullies and victims compared to the identification of teachers or peers (Cornell \& Brockenbrough, 2004). Second, we took only one-item criteria to determine a general role of students in peer bullying considering perceptions of school climate, which was in line with the original questionnaire (Cornell, 2012), but could have an impact on the validity of our results. Third, when we tested the construct validity of the SCBS questionnaire, the fit of the 3 -factor model was merely satisfactory, so we suggest that the structure of the Slovenian version of SCBS should be further examined in future studies.

Nevertheless, our findings enable some practical implications. First, it seems there is a need to raise awareness and sensitize pre-service teachers and teachers about ways of identifying peer bullying and for assertively and competently coping with it. Namely, the teachers are those who send clear messages about the acceptable behavior in school to the students by reacting and dealing with peer bullying, which consequently has an impact on students' behavior. Second, the results, at least indirectly, suggest that the programs for reducing peer bullying should be implemented not only in the group of teachers but also in the group of student observers, because it might encourage them to try to actively stop the bullies (Denny et al., 2015; Elliot et al., 2008; Pečjak \& Pirc, 2017).

\section{Conclusions}

The results of our study indicated different representations of individual forms of peer bullying among primary and secondary school students where verbal and social bullying is most common. This was probably due to lower sensitivity of all participants in the school environment for these two forms of bullying. At the same time, differences in the perceptions of school climate between various participants in peer bullying were established. It seems that especially bullies and victimbullies are driven by their perceptions to use aggressive behavior aimed at peers as a means of reaching their goals (social and other).

With our study we wanted to emphasize that one of the most effective approaches for reducing peer bullying at school is a supportive school climate (Pearce, Cross, Monks, Waters, $\&$ Falconer, 2011). This enables open communication between students and teachers (also about bullying), develops a sense of belonging to the school, and protects the students from bullying. Next to supportive school climate, A. Gregory et al. (2010) also emphasize a second complementary aspect of safe school environment - the enforcement of school discipline (structure). It is therefore critical that in school environment the rules about inadmissibility of bullying are clearly stated from teachers and other school staff and that this kind of behavior is immediately and consistently responded to, which was already warned about by Sullivan (2011) with his model of ripple effect in peer bullying and also by the model of planned behavior (Ajzen \& Madden, 1986).

Teachers' work in prevention and intervention of peer bullying at school is important because research in children and adolescents shows (e.g., Stormshak, Bierman, Bruschi, Dodge, \& Coie, 1999) that frequent behavior soon becomes a subjective norm from the students' perspective. This means they evaluate such behavior as acceptable. If there is a group norm in which certain forms of peer bullying are admissible, then, again in accordance with the model of planned behavior (Ajzen \& Madden, 1986), the probability of bullying increases. 


\section{References}

Adair, V., Dixon, R. S., Moore, D. W., \& Sutherland, C. M. (2000). Ask your mother not to make yummy sandwiches: Bullying in New Zealand secondary schools. New Zealand Journal of Educational Studies, 35(2), 207-221.

Ajzen, I., \& Madden, T. J. (1986). Prediction of goal-oriented behavior: Attitudes, intention and perceived behavioral control. Journal of Experimental Social Psychology, 22, 453-474.

Bandyopadhyay, S., Cornell, D. G., \& Konold, T. R. (2009). Validity of three school climate scales from the School Climate Bullying Survey. School Psychology Review, $38(3), 338-355$

Bauman, S., \& Del Rio, A. (2006). Preservice teachers' response to bullying scenarios: Comparing physical, verbal, and relational bullying. Journal of Educational Psychology, 98(1), 219-231.

Benitez, J. L., \& Justicia, F. (2006). Bullying: Description and analysis of the phenomenon. Granada, Spain: University of Granada.

Berger, K. (2007). Update on bullying at school: Science forgotten? Developmental Review, 27, 90-126.

Bradshaw, C., Sawyer, A., \& O’Brennan, L. (2007). Bullying and peer victimization at school: perceptual differences between students and school stuff. School Psychology Review, 35, 361-383.

Bronfenbrenner, U. (Ed.) (2004). Making human beings human: Bioecological perspectives on human development. Thousand Oaks, CA, USA: Sage.

Cohen, J., McCabe, E. M., Michelli, N. M., \& Pickeral, T. (2009). School climate: Research, policy, practice, and teacher education. Teachers College Record, 111, 180-213.

Cook, C. R., Williams, K. R., Guerra, N. G., Kim, T. E., \& Sadek, S. (2010). Predictors of bullying and victimization in childhood and adolescence: A meta-analytic investigation. School Psychology Quarterly, 25(2), 65-83.

Cornell, D. (2012). The school climate bullying survey (SCBS): Description and research summary. Retrieved from http://curry.virginia.edu/uploads/resourceLibrary/ School_Climate_Bullying_Survey_Description_for Distribution 5-22-12.pdf

Cornell, D. G., \& Brockenbrough, K. (2004). Identification of bullies and victims: A comparison of methods. Journal of School Violence, 3(2-3), 63-87.

Cornell, D. \& Sheras, P. (2003). School Climate Bullying Survey. Charlottesville, VA, USA: University of Virginia,Virginia Youth Violence Project.

Craig, K., Bell, D., \& Leschied, A. (2011). Preservice teachers' knowledge and attitudes regarding school-based bullying. Canadian Journal of Education, 34(2), 21-33.

Craig, W. M., Pepler, D., Connolly, J., \& Henderson, K. (2001). Dvelopmental context of peer harassment in early adolescence. In J. Juvonen \& S. Graham (Eds.), Peer harassment in the school: The plight of the vulneable and victimized (pp. 242-262). New York, NY, USA: The Guilford Press.
Davis, S., \& Nixon, C. (2011). What students say about bullying. Educational Leadership, 69(1), 18-23.

Denny, S., Peterson, E. R., Stuart, J., Utter, J., Bullen, P., Flemming, T., Ameratunga, S., Clark, T., \& Milfont, T. (2015). Bystanders intervention, bullying, and victimization: A multilevel analysis of New Zealand high school. Journal of School Violence, 14(3), 245-272.

Eliot, M., Cornell, D., Gregory, A., \& Fan, X. (2008). Supportive school climate and student willingness to seek help for bullying and threats of violence. Journal of School Psychology, 48(6), 533-553.

Fekkes, M., Pijpers, F. I., \& Verloove-Vanhorick, S. P. (2005). Bullying: Who, what, when and where? Involvement of children, teachers and parents in bullying behavior. Health Educational Research, 20(1), 81-90.

Goldstein, S. E., Young, A., \& Bold, C. (2008). Relational aggression at school: Associations with school safety and social climate. Journal of Youth and Adolescence, 37(6), 641-654.

Gottfredson, G. D., Gottfredson, D. C., Payne, A. A., \& Gottfredson, N. C. (2005). School climate predictors of school disorder: Results from a national study of delinquency prevention in schools. Journal of Research in Crime and Delinquency, 42(4), 414-444.

Gregory, A., Cornell, D., Fan, X., Sheras, P., Shih, T. H., \& Huang, F. (2010). Authoritative school discipline: High school practices associated with lower bullying and victimization. Journal of Educational Psychology, 102(2), 483-496.

Hong, J. S., \& Espelage, D. L. (2012). A review of research on bullying and peer victimization in school: An ecological system analysis. Aggression and Violent Behavior, 17(4), 311-322.

Hunter, S. C., \& Boyle, J. M. (2004). Appraisal and coping strategy use in victims of school bullying. British Journal of Educational Psychology, 74(1), 83-107.

Kessel Schneider, S., O’Donnell, L., Sueve, A., \& Coulter, R. W. S. (2012). Cyberbullying, school bullying, and psychological distress: A regional census of high school students. Research and Practice, 102(1), 171-178.

Kowalski, R. M., Giumetti, G. W., Schroeder, A. N., \& Reese, H. H. (2012). Cyber bullying among college students: Evidence from multiple domains of college life. In L. A. Wankel \& C. Wankel (Eds.), Misbehavior Online in Higher Education (pp. 293-321). Bingley, United Kingdom: Emerald.

Lacey, A., \& Cornell, D. (2011). The impact of bullying climate on schoolwide academic performance. Paper presented at the American Psychological Association Annual Convention, Washington, DC, USA.

Marsh. H. W., Nagengast, B., Morin, A. J., Parada, R. H., Craven, R. G., \& Hamilton, L. R. (2011). Construct validity of the multidimensional structure of bullying and victimization: An application of exploratory structural equation modeling. Journal of Educational Psychology, 103(3), 701-732. 
Muthén L. K., \& Muthén, B. O. (1998-2010). Mplus user's guide ( $6^{\text {th }} e$ d.). Los Angeles, CA, USA: Muthén \& Muthén.

Olweus, D. (1993). Victimization by peers: Antecedents and long-term outcomes. In K. H. Rubin \& J. B. Asendorpf (Eds.), Social withdrawal, inhibition, and shyness in childhood (pp. 315-41). Hillsdale, NJ, USA: LEA.

Olweus, D. (1995). Trpinčenje med učenci, kaj vemo in kaj lahko naredimo [Bullying at school: What we know and what we can do]. Ljubljana, Slovenia: Zavod RS za šolstvo.

Pearce, N., Cross, D., Monks, H., Waters, S., \& Falconer, S. (2011). Current evidence of best practice in wholeschool bullying intervention and its potential to inform cyberbullying interventions. Australian Journal of Guidance and Counseling, 21(1), 1-21.

Pečjak, S. (2015). Medvrstniško nasilje v šoli [Peer bullying at school]. Ljubljana, Slovenia: Znanstvena založba Filozofske fakultete v Ljubljani.

Pečjak, S., \& Pirc, T. (2015). Predictors and forms of intervention in peer bullying: Preservice teachers vs. teachers. The New Educational Review, 39(1), 264-276.

Pečjak, S., \& Pirc, T. (2017). Bullying and perceived school climate: Victims' and bullies' perspective. Studia psychologica, 59(1), 22-33.

Polak, A., Smrtnik Vitulić, H., \& Vošnjak, Š. (2011). Doživljanje različnih vlog v situacijah vrstniškega nasilja [Experiencing different roles in situations of bullying]. Socialna pedagogika, 15(3), 205-222.

Posnic, K., \& Košir, K. (2016). Medvrstniško nasilje, kot ga zaznavajo učitelji in učenci osnovne šole (Bullying in Basic School: the Perspectives of Teachers and Pupils). Revija za elementarno izobrazevanje, 9(3), 5.

Rigby, K. (2016). Bullying in Australian schools: Multiple perceptions of bullying. Paper presented at National Centre against Bullying Conference, 28th-29th July 2016, Melbourne. Retrived from http//www.kenrigby.net

Rigby, K., \& Bagshaw, D. (2003). Prospects of adolescent students collaborating with teachers in addressing issues of bullying and conflict in schools. Educational Psychology, 23(5), 535-546.

Salmivalli, C., \& Voeten, M. (2004). Connections between attitudes, group norms, and behaviour in bullying situations. International Journal of Behavioral Development, 28(3), 246-258.

Skumavc, G. (2016). Spletno nadlegovanje in učenci $s$ posebnimi potrebami [Cyberbullying in students with special needs] (unpublished master's thesis). Pedagoška fakulteta Univerze v Ljubljani, Slovenia.

Smith, P. K., Ananiadou, K., \& Cowie, H. (2003). Intervention to reduce school bullying. Canadian Journal of Psychiatry, 48(9), 295-303.

Smith, P. K., Mahdavi, J., Carvalho, M., Fisher, S., Russell, S., \& Tippett, N. (2008). Cyberbullying: Its nature and impact in secondary school pupils. Journal of Child Psychology and Psychiatry, 49(4), 376-385.
Smith, P. K., Talamelli, L., Cowie, H., Naylor, P., \& Chauhan, P. (2004). Profiles of non-victims, escaped victimis, continuing victims, and new victims in school bullying. British Journal of Educational Psychology, 74(4), 565-581.

Stormshak, E., Bierman, K., Bruschi, C., Dodge, K., \& Coie, J. (1999). The relation between behaviour and peer preference in different classroom contexts. Child Development, 70(1), 169-182.

Sullivan, K. (2011). The anti-bullying handbook. London: Oxford University Press.

Ttofi, M. M., \& Farrington, D. P. (2011). Effectiveness of school-based programs to reduce bullying: A systematic and meta-analytic review. Journal of Experimental Criminology, 7(1), 27-56.

U.S. Department of Education (2015). Student report of bullying and cyber-bullying: Results from the 2013 school crime supplement to the national crime victimization survey. Washington, DC, USA: Author.

Waasdorp, T. E., \& Bradshaw, C. P. (2011). Examining student responses to frequent bullying: a latent class approach. Journal of Educational Psychology, 103(2), 336-352.

Waasdorp, T. E., Pas, E. T., O’Brennan, L. M., \& Bradshaw, C. P. (2011). A multilevel perspective on the climate of bullying: Discrepancies among students, school staff, and parents. Journal of School Violence, 10(2), 115-132.

Wang, J., Iannotti, R. J., \& Nansel, T. R. (2009). School bullying among adolescents in the United States: Physical, verbal, relational, and cyber. Journal of Adolescent Health, 45(4), 368-375.

Wong, D. S., Lok, D. P., Wing Lo, T., \& Ma, S. K. (2008). School bullying among Hong Kong Chinese primary schoolchildren. Youth Society, 40(1), 35-54.

World Health Organization (2004). School mobbing: Bullying and violence against children. Retrieved from http:// www.acosoescolar.com/inicio/inicio.html 